THE LANGUAGE OF LITERATURE

General Editor: N. F. Blake

Professor of English Language and Linguistics

University of Sheffield 


\section{THE LANGUAGE OF LITERATURE}

General Editor: N. F. Blake

Professor of English Language and Linguistics

University of Sheffield

Published titles

An Introduction to the Language of Literature

The Language of Shakespeare

N. F. Blake

N. F. Blake

The Language of Chaucer

David Burnley

The Language of Wordsworth and Coleridge

The Language of Irish Literature

The Language of $D$. H. Lawrence

Frances Austin

Loreto Todd

The Language of Thomas Hardy

The Language of James Joyce

The Language of Drama

Allan Ingram

Raymond Chapman

Katie Wales

The Language of Jane Austen

David Birch

Myra Stokes

Further titles are in preparation

\section{Series Standing Order}

If you would like to receive future titles in this series as they are published, you can make use of our standing order facility. To place a standing order please contact your bookseller or, in case of difficulty, write to us at the address below with your name and address and the name of the series. Please state with which title you wish to begin your standing order. (If you live outside the United Kingdom we may not have the rights for your area, in which case we will forward your order to the publisher concerned.)

Customer Services Department, Macmillan Distribution Ltd, Houndmills, Basingstoke, Hampshire, RG21 2XS, England. 


\section{The Language of James Joyce}

KATIE WALES

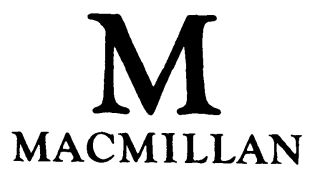


All rights reserved. No reproduction, copy or transmission of this publication may be made without written permission.

No paragraph of this publication may be reproduced, copied or transmitted save with written permission or in accordance with the provisions of the Copyright, Designs and Patents Act 1988, or under the terms of any licence permitting limited copying issued by the Copyright Licensing Agency, 33-4 Alfred Place, London WC1E 7DP.

Any person who does any unauthorised act in relation to this publication may be liable to criminal prosecution and civil claims for damages.

First published 1992

Published by

MACMILLAN EDUCATION LTD

Houndmills, Basingstoke, Hampshire RG21 2XS

and London

Companies and representatives

throughout the world

Typeset by Footnote Graphics,

Warminster, Wiltshire

British Library Cataloguing-in-Publication Data

Wales, Katie

The language of James Joyce. - (The language of

literature)

I. Title II. Series

823

ISBN 978-0-333-48055-7 ISBN 978-1-349-21873-8 (eBook)

DOI 10.1007/978-1-349-21873-8 
To Barbara Hardy and Fritz Senn 


\section{Contents}

Preface $\quad$ ix

Acknowledgements and Editions Used $\quad$ xi

Abbreviations and Symbols xii

1 Joyce and Irish English 1

1.1 Introduction: The History of English in Ireland 1

1.2 Joyce and Hiberno-English 7

1.3 Joyce and Anglo-Irish Literature 25

1.4 Conclusion: The Joycean Paradox 32

2 Joyce and Rhetoric: Dubliners and $A$ Portrait of the Artist as a Young Man $\quad 34$

2.1 Introduction: Joyce and Rhetoric 34

2.2 Repetition in Dubliners 37

2.3 Emotive Rhetoric in A Portrait of the Artist as a
Young Man

2.4 Conclusion: A Portrait of the Artist as a Rhetorician $\quad 66$

3 Joyce's Voices in Ulysses

3.1 The Voices of Ulysses $\quad 68$

3.2 'The Steady Monologuy of the Interiors' ( $F W: 119) \quad 71$

3.3 The 'Inner Voices' of Stephen Dedalus and Leopold Bloom 75

3.4 The Female Voice: Molly's Monologue 90

3.5 Conclusion: The Dialogue of Voices in Ulysses 101

4 The Play of Language in Ulysses 105

4.1 Introduction: Joyce and the Ludic(rous) 105

4.2 The Play of Sound and Symbol 106 
viii Contents

4.3 Dislocutions of Syntax 110

4.4 Lexical Creativity 115

4.5 Licences of Meaning 118

4.6 Comic Word-Play 122

4.7 The Art of Parody 128

4.8 Conclusion: A Portrait of the Artist as a Joker 131

5 The 'Ideal Reader' of Finnegans Wake 133

5.1: Introduction: To Read, or Not to Read ... . 133

5.2 The Reader's Progress to Finnegans Wake 134

5.3 Putting the Language to Sleep 137

5.4 Here Comes Everything: Endlessly Repeated 141

5.5 'The Keys to. Given!' (FW:628) 146

5.6 Conclusion: The 'Ideal Reader' of Finnegans Wake 154 Appendix to Chapter 5

$\begin{array}{lr}\text { Notes } & 160\end{array}$

Further Reading $\quad 168$

Index 177 


\section{Preface}

No student or lover of language can afford to ignore the writings of James Joyce; just as no student of the writings of James Joyce can afford to ignore their language. It is hard to see how F. R. Leavis writing in The Great Tradition (1948) should see D. H. Lawrence as the more creative master of language, and Ulysses as a 'dead end'. Joyce, this witty Irish polyglot English-teaching philologist, wrote some of the most influential fiction of the early twentieth century, and is surely the greatest manipulator of literary language since Shakespeare.

Surprisingly, however, there have been very few book-length studies of Joyce's language. The task is certainly daunting: not only because of the length and complexity of Joyce's works, but also because there are many different ways of approaching the subject, as many scholarly articles reveal. In the twenty years or so since the publication of Burgess's book Joysprick (1973), studies of Joyce's style, especially in Ulysses and Finnegans Wake, have been much influenced by, for example, the theories of Bakhtin, readerresponse criticism, feminism and deconstruction. In this book, I have tried to maintain a linguistic/stylistic perspective on Joyce's use of language, and so have assessed such theories from this perspective where they have proved relevant: most notably Bakhtin and the 'dialogic' and 'interior monologue'; 'women's language' and Molly Bloom, in Chapter 3. I have also tried to devote attention to those aspects of Joyce's language which have been relatively neglected, or about which students are not likely to know a great deal: notably Joyce's use of Hiberno-English (Chapter 1) and of rhetoric (Chapter 2). These aspects of Joyce's use of language, I would stress, are the 'base' on which his linguistic creativity is built.

This is primarily a book for students. This is not to say that in the process of its composition I have not been much stimulated by 


\section{$\mathrm{x}$ Preface}

Joycean scholarship and personal interchanges with many Joyce scholars, notably the late Charles Peake, George Sandulescu and Fritz Senn. It is written with the minimum of technical terminology in order to encourage students to explore this important dimension of Joyce's work, which will give them much edification and delight, without feeling that they need to know a great deal about linguistics beforehand. In sum, my aim has been to share my own enthusiasm for Joyce by showing how an understanding of different significant aspects of Joyce's language in each of his major prose works can contribute to an appreciation of their stylistic texture, techniques and meaning.

I make no apologies for the length of the Further Reading section at the end of the book. It is intended to be a comprehensive and up-to-date guide to the most significant works on Joyce's language for readers who wish to explore this dimension further. The core consists of works of specific relevance to the themes of each chapter; other works cited may be of general relevance to the whole range of his fiction, or to the 'major' works of Ulysses or Finnegans Wake. There are also articles on specific topics in specific texts, which explore ideas beyond the scope of my chapters here. 


\section{Acknowledgements and Editions Used}

The author and publishers wish to thank the following for permission to use copyright material:

The Society of Authors as the literary representatives of the Estate of James Joyce for all extracts from Dubliners, A Portrait of the Artist as a Young Man, Ulysses and Finnegans Wake.

Jonathan Cape (London) and Viking Penguin, a division of Penguin Books USA Inc., for extracts from Dubliners, copyright 1916 by B. W. Huebsch, Inc., definitive text (C) 1967 by the Estate of James Joyce.

Jonathan Cape (London) and Viking Penguin, for extracts from $A$ Portrait of the Artist as a Young Man, copyright 1916 by B. W. Huebsch, 1944 by Nora Joyce, (C) 1964 by the Estate of James Joyce. The Bodley Head (London) and Random House, Inc., New York for extracts from Ulysses, the corrected text, copyright (C) 1986, Random House, Inc.

Viking Penguin USA for extracts from Finnegans Wake, copyright 1939 by James Joyce, renewed (C) 1967 by George Joyce and Lucia Joyce.

References in the text are to the following editions: Stephen Hero $(\mathrm{SH})$, revised edition by John J. Slocum and Herbert Cahoon, Jonathan Cape, London, 1969; Dubliners $(D)$, the corrected text, with an explanatory note by Robert Scholes, Paladin, London, 1988; A Portrait of the Artist as a Young Man (PAYM), the definitive text edited by Richard Ellmann, Paladin, London, 1988; Ulysses, the corrected text edited by Hans Walter Gabler, Student's Edition, Penguin, London, 1986 - references are to episode and line number, e.g. 3. 206; Finnegans Wake $(F W)$, third edition, Faber \& Faber Ltd, London, 1975. 


\section{Abbreviations and Symbols}

adj. adjective

adv. adverb

ALP Anna Livia Plurabelle

cp. compare

D Dubliners

DS direct speech

EE English English

Fr. French

FW ('the Wake') Finnegans Wake

Ger. German

Gk Greek

HE Hiberno-English

IM interior monologue

Ir. Irish (Gaelic)

Lat. Latin

NE Modern (New) English

NHE Northern Hiberno-English

NP noun phrase

Nt. dial. Northern dialect

$\mathrm{O}$ object

obs. obsolete

OE Old English

$O E D \quad$ Oxford English Dictionary

OF Old French

PAYM (A Portrait) A Portrait of the Artist as a Young Man

$\mathrm{RP} \quad$ received pronunciation

SH Stephen Hero

SHE Southern Hiberno-English

sl. slang

vb. verb

WO word order 
$\quad>\quad$ enclose graphic symbols (letters of the alphabet)

/ / enclose phonemic symbols

$\emptyset \quad$ zero 